\begin{tabular}{|l|l|l||}
\hline \multicolumn{2}{|c|}{ PublisherInfo } \\
\hline \hline PublisherName & $:$ & BioMed Central \\
\hline \hline PublisherLocation & $:$ & London \\
\hline \hline PublisherImprintName & $:$ & BioMed Central \\
\hline \hline
\end{tabular}

\title{
Re-evaluating the yeast genome
}

\begin{tabular}{|l|l|l||}
\hline \multicolumn{2}{|c|}{ ArticleInfo } \\
\hline \hline ArticleID & $:$ & 4368 \\
\hline \hline ArticleDOI & $:$ & $10.1186 /$ gb-spotlight-20020103-01 \\
\hline \hline ArticleCitationID & $:$ & spotlight-20020103-01 \\
\hline \hline ArticleSequenceNumber & $:$ & 34 \\
\hline \hline ArticleCategory & $:$ & Research news \\
\hline \hline ArticleFirstPage & $:$ & 1 \\
\hline \hline ArticleLastPage & $:$ & 2 \\
\hline \hline & $:$ & RegistrationDate : 2002-01-03 \\
ArticleHistory & $:$ & OnlineDate \\
\hline \hline ArticleCopyright & $:$ & BioMed Central Ltd2002-01-03 \\
\hline \hline ArticleGrants & $:$ & \\
\hline \hline ArticleContext & $:$ & 130593311 \\
\hline \hline
\end{tabular}




\section{Jonathan B Weitzman}

Email: jonathanweitzman@hotmail.com

Finding genes within genomic sequence remains a major challenge, even for a genome that has undergone extensive annotation such as that of the yeast Saccharomyces cerevisiae. In the January issue of Nature Biotechnology, Anuj Kumar and colleagues at Yale University describe an integrated genomics approach for gene hunting (Nature Biotechnology 2002, 20:58-63). Kumar et al. began with a large-scale insertional mutagenesis screen using a modified transposon as a LacZ-reporter gene-trap. Candidate genes were then verified by microarray analysis using strand-specific 60-mer oligonucleotides. They also used computational analysis to compare potential genes with proteome data from other species, before defining novel genes. This approach led them to identify 137 previously missed genes, many of which encode for short polypeptides or are antisense to annotated genes. Both of these classes of genes are often missed by traditional gene-hunting procedures.

\section{References}

1. Life with 6000 genes.

2. Nature Biotechnology, [http://biotech.nature.com]

3. Yale University, [http://www.yale.edu] 